CARPINEJAR, Fabrício. Terceira sede. São Paulo: Escrituras Editora, 2001. 80p.

\title{
A sobrevida do amor: o lirismo revisitado
}

Vívien Gonzaga e Silva I UFMG

Existem várias formas de se ler poesia; uma delas é esquecendose - ou, pelo menos, fingindo-se esquecer - de boa parte do instrumental crítico que nos franqueia o acesso a tudo o que podemos entender por texto, ao mesmo tempo em que nos priva, quase sempre, de experiências que apenas uma leitura movida pela empatia pode oferecer - experiências, é bom que se diga, a caminho da extinção.

É dessa forma que devemos ler cada um dos dez poemas elegíacos de Carpinejar, reunidos em seu trabalho mais recente, Terceira sede (São Paulo: Escrituras Editora, 80p.), publicado em 2001. Assim, pois, como se estivéssemos diante de uma perda irreparável, como se concentrássemos em nós o lamento por todos os amores - a qualquer momento, precocemente - findos, como se estivéssemos imobilizados pela perpétua ausência do outro, já confundido em nossa noção de futuro, é que podemos fruir as imagens, tão perturbadoras quanto vitais, provindas da escrita delicada do poeta e jornalista gaúcho Fabrício Carpi Nejar.

É que a morte - é essa a extrema ausência - implica delicadeza no olhar, o que não quer dizer fragilidade. Antes, é a coragem de assumir o 
próprio temor como uma antiga cicatriz pela qual já se adquiriu certa estima, apenas porque é nossa, apenas porque faz lembrar uma experiência intransferível. O amor que se viveu - e é essa a experiência intransferível -, quando morto, desaparecido do nosso olhar, do nosso tato, do nosso olfato, acomoda-se numa memória que é preciso revisitar: "O porão tem vida própria e respira / o que jogamos fora".

Entrar nesse espaço é, talvez, a única possibilidade de sobreviver à falta, à incompletude que nos define como potenciais amantes e que nos confere o melhor do humano, ligando-nos ao que está sempre além de nós mesmos: ao outro. Provavelmente por isso seja sempre tão difícil se desfazer dos objetos - presenças silenciosas - dos mortos que amamos (exatamente assim, com esse amor expresso no verbo ambíguo que mescla pretérito e presente): "Evito descerrar teu armário, / é como descer junto na cova. / Como avisar teus pertences que foste embora?". E esta não é, certamente, uma experiência exclusiva de poetas, mas, pela poesia - se a aceitamos como tal é possível também a nós, que muitas vezes tratamos o lirismo como as "uvas verdes” da fábula de Esopo, é possível a nós, leitores, ressignificar não apenas nossas perdas, mas, principalmente, os intervalos que se contam entre elas. É isso que se espera de uma boa leitura. É isso que se espera de um bom exercício de escrita.

Em Terceira sede, esse exercício é desenvolvido com habilidade, parecendo contestar a pouca idade do autor - hoje se aproximando dos 30 anos - pelo artifício do verbo: "Palavras, palavras, destruíram as que me dariam significado. / Mudei de endereço e nenhum sinônimo me localiza"; versos que pontuam a constatação precoce que só poderia vir à tona pela voz de um eu lírico septuagenário. De que outra forma, senão pelo fingimento, poderia o jovem Carpinejar apropriar-se de tradições literárias tão remotas e compor suas elegias, a nênia dolorosa dedicada à amada morta: "Tenho uma desaparecida que espero para jantar. / O pão, como a sala, esvaziado da ternura do miolo.”? E de que outra forma pode-se ter a dimensão do outro em nós - desse nosso sinônimo: "Não nascemos um para o outro, mas um no outro."?

Quanto a nós, leitores, de que outro modo seria possível aproveitar a habilidade de Carpinejar e sua falta de "talento para esquecer", senão ignorando a ardilosa informação que antecipa suas elegias - e, apenas se quisermos, nos permite desconstruí-las: "O livro é de 2045, escrito aos 72 anos. Como posso ter morrido antes, decidi antecipar a velhice." 